\title{
The effect of condensed tannins from heated and unheated cottonseed on the ileal digestibility of amino acids for the growing rat and pig
}

\author{
BY FENG YU*, P. J. MOUGHAN† AND T. N. BARRY \\ Department of Animal Science, Massey University, Palmerston North, New Zealand \\ AND W. C. MCNABB \\ AgResearch, Grassland Research Centre, Palmerston North, New Zealand
}

(Received 13 November 1995 - Accepted 3 January 1996)

\begin{abstract}
The effect of condensed tannins (CT) from heated and unheated cottonseed on the apparent ileal digestibility of amino acids for the growing rat and pig was determined. In Expt 1, twenty-four rats were allocated to four semi-purified diets which contained cottonseed kernel and hulls as the only protein source. Two of the diets contained unheated solvent-extracted cottonseed kernel and hulls, while the remaining two diets contained similar material but which had been heat-treated by autoclaving at $110^{\circ}$ for $120 \mathrm{~min}$. In Expt 2, twelve rats and twelve pigs were fed on four semi-purified diets containing commercial cottonseed meal (CSM) as the only protein source. $\mathrm{Cr}_{2} \mathrm{O}_{3}$ was added to all diets as an indigestible marker. For each pair of diets in both experiments, PEG was either included or excluded. The effect of CT was assessed by comparing control animals (-PEG; CT acting) with PEGsupplemented animals (+PEG; CT inactivated). Hleal contents from the terminal 150 and $450 \mathrm{~mm}$ of ileum were collected at slaughter, $7 \mathrm{~h}$ from the start of feeding, for the rats and pigs respectively. Apparent ileal amino acid digestibility for rats fed on the diet containing cottonseed kernel and hulls was significantly depressed by the heat treatment, particularly for lysine and threonine. On average, apparent ileal amino acid digestibility in the diets without PEG was decreased from 0.80 to 0.70 by heat treatment. Dietary cottonseed CT depressed apparent ileal protein digestibility in the pig and in the rat. The addition of PEG to the diets significantly increased the apparent ileal digestibility of $\mathbf{N}$ and some amino acids for the pigs and the rats. The mean increase in apparent ileal digestibility due to PEG addition for the fourteen amino acids was 2 percentage units in both species fed on the commercial CSM diets, and 2 or 4 percentage units in rats fed on the unheated or the heated cottonseed kernel and hull diets respectively. The effect of PEG was similar in the heated and unheated cottonseed kernel and hulls for most amino acids, but apparent ileal digestibilities of threonine, tyrosine and lysine were increased more by PEG in heated than in unheated CSM. Apparent ileal $\mathrm{N}$ digestibility was lower in the pig than in the rat. For several of the amino acids there were significant animal species differences in apparent ileal digestibility. Studies into the effects of cottonseed CT should be carried out in the target animal species. The commercial CSM had a low apparent ileal amino acid digestibility overall, particularly for the essential amino acids lysine and threonine. It was concluded that effects of heating did not eliminate the reversible reactivity of cottonseed CT on amino acid digestion in rats and pigs but rather appeared to increase it for threonine, tyrosine and lysine in Expt 1, causing large reductions in apparent ileal digestibility of these amino acids.
\end{abstract}

Cottonseed: Condensed tannin: Ileum: Amino acids: Heat treatment

Cottonseed meal (CSM) is commonly used as a protein supplement in the formulation of pig diets, but its nutritive value is lower than that predicted on the basis of its chemical

\footnotetext{
* Present address: Rowett Research Institute, Bucksburn, Aberdeen AB2 9SB.

$\dagger$ For reprints.
} 
composition (Batterham et al. 1990). This is thought to be due to the effects of the processing of cottonseed during oil extraction, and to the presence of several antinutritional factors (ANF), such as gossypol and condensed tannins (CT; Terrill et al. 1992; Yu et al. 1993). The heating of CSM during commercial processing binds free gossypol to the $\epsilon$-amino group of lysine (Berardi \& Goldblatt, 1980), but may also cause other detrimental effects (Batterham, 1992). Free amino groups, and mainly the $\epsilon$-amino group of lysine, may react with other groups to form enzyme-resistant inter- and intra-molecular bonds. The solubility and digestibility of the protein is thereby reduced and the time-course of digestion is prolonged (Ford \& Shorrock, 1971). CT are found in cottonseed hulls, but not in cottonseed kernel (Yu et al. 1993). Dietary CT have been shown to reduce bodyweight gain, impair feed conversion efficiency and reduce the apparent digestibility of protein and amino acids in single-stomached species (Longstaff \& McNab, 1991; Jansman, 1993; Yu et al. 1996 b). Our previous work with the growing rat has shown that the addition of cottonseed hulls to a semi-purified diet significantly increased endogenous ileal amino acid loss (Yu et al. 1995b), whilst hulls, partly due to their CT content, decreased the apparent and true ileal digestibility of amino acids in cottonseed kernel (Yu et al. 1996b). The latter study used unheated solvent-extracted cottonseed kernel as the major dietary protein source, and there is a need to establish whether the latter finding also holds for heattreated materials. High temperatures are used in the manufacture of CSM.

In rats the consumption of high-tannin sorghums or high-tannin faba-bean (Vicia faba L.) hulls increased the relative weight of the parotid glands and there was an increased synthesis and secretion of proline-rich proteins with a high affinity for binding tannins (Mehansho et al. 1983; Jansman, 1993), resulting in a higher endogenous $\mathrm{N}$ excretion in the faeces. The existence of a similar mechanism in pigs fed on tannin-rich faba bean hulls has not been demonstrated (Jansman, 1993). The quantitative effects of CT in CSM on the apparent ileal digestibility of protein and amino acids in pigs have not been determined.

The objectives of the present study were first to determine whether the effects of CT in unheated CSM on apparent ileal amino acid digestibility also hold for heat-treated CSM, second to determine quantitatively the effect of cottonseed CT on the apparent ileal digestibility of protein and amino acids in the growing pig and, third, to compare the effects of CT in CSM on the apparent ileal digestibility of protein and amino acids in growing rats and pigs.

The effect of heat treatment on protein digestibility was determined by comparing the digestion of a cottonseed kernel and hulls mixture with or without heat-treatment. The temperature and duration of heating were similar to those used in commercial processing. The effect of CT was assessed by determining the digestibility of nutrients in the presence or absence of PEG (molecular weight (MW) 3500; Union Carbide, Danbury, CT, USA). PEG binds strongly to $C T$ and can be used to displace protein completely from CT-protein complexes (Jones \& Mangan, 1977). The effects of CT can be quantified by comparing animals receiving a control diet (CT acting) with animals given the same diet but with PEG added (CT inactivated). In the present work PEG was added at a rate of $2 \mathrm{mg} / \mathrm{mg}$ total CT to maximize displacement of protein from the CT-protein complexes ( $\mathrm{Yu}$ et al. 1995a). Previous studies (Yu et al. 1995b;1996b) have established that adding PEG to the diet in the absence of CT has no effect on protein digestion.

MATERIALS AND METHODS

Preparation of cottonseed products

Expt 1. Delinted whole cottonseed (var. Siokra L22), supplied by Cottonseed Distributors Ltd, Wee Waa, NSW, Australia, was cracked using a Crushing-Mill (AB Thorell and 
Persson, Uppsala, Sweden), and separated into kernels and hulls using air flow, at the Seed Technology Centre, Massey University, with final manual separation. The separated kernels were freeze-dried for $48 \mathrm{~h}$, ground to pass through a $2 \mathrm{~mm}$ diameter sieve, and the oil and gossypol were partially extracted using hexane and then acetone in water using a modification of the Pons \& Eaves (1967) procedure, as described by Yu et al. (1995a). Finally, the extracted cottonseed kernels and hulls were re-ground to pass through a $1 \mathrm{~mm}$ diameter sieve and were stored at $-20^{\circ}$.

Solvent-extracted cottonseed kernels $(3 \mathrm{~kg})$ were mixed with $500 \mathrm{~g}$ ground hulls $(166.7 \mathrm{~g}$ hulls $/ \mathrm{kg}$ kernel). The resulting mixtures were then divided into two samples. One of the two samples was heat-treated by autoclaving for $120 \mathrm{~min}\left(110^{\circ} ; 0.5 \mathrm{~kg} / \mathrm{cm}^{2}\right.$ pressure with $70-100 \mathrm{~g}$ moisture $/ \mathrm{kg}$ ) in flat pans at a thickness of about $20 \mathrm{~mm}$. The second sample remained unheated.

Expt 2. Commercial CSM was supplied by the Narrabri mill of Cargill Oilseeds Ltd, Australia (pre-press solvent-extraction method, using hexane as the solvent to extract oil) and was sifted through a $1.0 \mathrm{~mm}$ screen.

\section{Animals and diets}

Expt 1. Twenty-four Sprague-Dawley rats (twelve male and twelve female; body weight 178 (SD 8.5) g), which had been weaned at 4 weeks of age, were reared on a high-quality diet at the Small Animal Production Unit, Massey University. The animals were kept individually in raised stainless-steel cages with wire-mesh floors, at $20 \pm 2^{\circ}$ and with a $12 \mathrm{~h}$ light-dark cycle. Animals were randomly assigned to four experimental diets, with six animals (three males and three females) on each dietary treatment.

The four semi-purified diets were formulated (Table 1) based on maize starch, and contained solvent-extracted cottonseed kernel and hulls as the only protein source. $\mathrm{Cr}_{2} \mathrm{O}_{3}$ was added to all diets as an indigestible marker compound. Two of the diets contained unheated solvent-extracted cottonseed kernel and unheated hulls, whilst the remaining two diets contained the heated materials. For each pair of diets, PEG was either included or excluded.

Expt 2. Twelve entire male pigs (body weight 24 (SD 1.2) $\mathrm{kg}$ ), supplied by the Pig Research Unit, Massey University, and twelve male Sprague-Dawley rats (body weight 192 (SD 4.5) g), supplied by the Small Animal Production Unit, Massey University, were used as experimental animals. Both the rats and pigs were kept individually in metabolism cages, in a temperature-controlled room $\left(20 \pm 2^{\circ}\right)$ and with a $12 \mathrm{~h}$ light-dark cycle. Animals from each species were randomly assigned to two experimental diets, with six animals on each dietary treatment.

The two semi-purified diets were formulated (Table 1) for each species based on maize starch and containing CSM as the only protein source. $\mathrm{Cr}_{2} \mathrm{O}_{3}$ was added as an indigestible marker and PEG was added to one of the diets for each pair to allow the effect of the CT to be distinguished.

\section{Experimental procedure}

The animals in both Expts 1 and 2 were fed on a semi-purified casein-based preliminary diet for $2 \mathrm{~d}$, after which they were given their respective experimental diet for $14 \mathrm{~d}$. For the rats the diets were offered in stainless-steel feeders, with the feeder being placed in the cage for $10 \mathrm{~min}$ at hourly intervals (08.30-16.30 hours). The training was achieved within $7 \mathrm{~d}$. The meal intake of the rats was set at 0.73 of the ad libitum digestible energy intake (National Research Council, 1978), and this was sufficient to maintain substantial growth rates over the trial period. For the pigs the diets were offered as a wet mash for a single $3 \mathrm{~h}$ period $(09.00-12.00$ hours) for the first $10 \mathrm{~d}$. From day 11 to the last day of study, each pig was 
Table 1. Ingredient and determined chemical compositions of diets based on solvent-extracted cottonseed kernel and hulls and commercial cottonseed meal (CSM) for the growing rats and pigs

\begin{tabular}{|c|c|c|c|c|c|c|c|c|}
\hline & \multicolumn{4}{|c|}{ Expt 1} & \multicolumn{4}{|c|}{ Expt 2} \\
\hline & \multicolumn{4}{|c|}{ Cottonseed kernel and hulls diet* } & \multicolumn{4}{|c|}{ CSM diet } \\
\hline & \multicolumn{2}{|c|}{ Unheated } & \multicolumn{2}{|c|}{ Heated } & \multicolumn{2}{|c|}{ Rat } & \multicolumn{2}{|c|}{ Pig } \\
\hline & $\overline{\mathrm{PEG}}-$ & $\mathrm{PEG}+$ & PEG - & $\mathrm{PEG}+$ & PEG - & $\mathrm{PEG}+$ & $\mathrm{PEG}-$ & PEG + \\
\hline \multicolumn{9}{|l|}{ Ingredient ( $\mathrm{g} / \mathrm{kg}$ air dry) } \\
\hline Cottonseed kernel & 300 & 300 & 300 & 300 & - & - & - & - \\
\hline Cottonseed hulls & 50 & 50 & 50 & 50 & - & - & - & - \\
\hline Commercial CSM & - & $\ldots$ & - & - & 400 & 400 & 400 & 400 \\
\hline PEG & - & 6 & - & 6 & - & 12 & - & 12 \\
\hline Maize starch & 444 & 438 & 444 & 438 & 394 & 382 & 394 & 382 \\
\hline Sucrose & 100 & 100 & 100 & 100 & 100 & 100 & 100 & 100 \\
\hline Maize oil & 50 & 50 & 50 & 50 & 50 & 50 & 50 & 50 \\
\hline Dicalcium phosphate & 24 & 24 & 24 & 24 & 24 & 24 & 24 & 24 \\
\hline $\mathrm{NaCl}$ & 5 & 5 & 5 & 5 & 5 & 5 & 5 & 5 \\
\hline $\mathrm{MgSO}_{4}$ & 2 & 2 & 2 & 2 & 2 & 2 & 2 & 2 \\
\hline $\mathrm{K}_{2} \mathrm{CO}_{3}$ & 4 & 4 & 4 & 4 & 4 & 4 & 4 & 4 \\
\hline Mineral and vitamin premixi & 15 & 15 & 15 & 15 & 15 & 15 & 15 & 15 \\
\hline $\mathrm{Cr}_{2} \mathrm{O}_{3}$ & 6 & 6 & 6 & 6 & 6 & 6 & 6 & 6 \\
\hline \multicolumn{9}{|l|}{ Nutrient (g/kg DM) } \\
\hline OM & 922 & 921 & 924 & 921 & 919 & 921 & 915 & 915 \\
\hline Crude protein & 175 & 180 & 177 & 183 & 197 & 194 & 202 & 201 \\
\hline Oil & 49 & 49 & 44 & 44 & 27 & 31 & 31 & 28 \\
\hline NDF & 67 & 66 & 72 & 70 & 54 & 56 & 56 & 56 \\
\hline $\mathrm{ADF}$ & 35 & 37 & 38 & 39 & 32 & 33 & 33 & 31 \\
\hline Lignin & 18 & 15 & 15 & 12 & 12 & 10 & 11 & 11 \\
\hline Gross energy (MJ/kg) & 18.7 & 18.9 & $18 \cdot 5$ & $18 \cdot 7$ & $18 \cdot 2$ & $18 \cdot 3$ & $18 \cdot 1$ & $17 \cdot 7$ \\
\hline Free gossypol (mg/kg) & 240 & 230 & 160 & 170 & 280 & 260 & 290 & 270 \\
\hline \multicolumn{9}{|l|}{ Condensed tannin } \\
\hline Total (calculated) & $2 \cdot 8$ & $2 \cdot 8$ & $2 \cdot 0$ & $2 \cdot 0$ & $4 \cdot 2$ & $4 \cdot 2$ & $4 \cdot 2$ & $4 \cdot 2$ \\
\hline
\end{tabular}

PEG -, no PEG in the diet; PEG +, PEG (molecular wt 3500) included in the diet; OM, organic matter; NDF, neutral-detergent fibre; $A D F$, acid-detergent fibre.

* Cottonseed kernel $(300 \mathrm{~g} / \mathrm{kg})+50 \mathrm{~g}$ hulls $/ \mathrm{kg}$; for details of preparation, see pp. $360-361$.

$\dagger$ For rat diets: Rat Pellet Premix 9327; Technik Products, Auckland, New Zealand. For pig diets: DanmixPig Grower and Finisher, Nutritech International Ltd, Auckland, New Zealand.

$\$$ Means of duplicate determinations.

fed at hourly intervals (08.30-16.30 hours) with equal-sized meals. Each meal was mixed with water $(1: 1 ; \mathrm{w} / \mathrm{v})$ before feeding. The same relative level of meal intake was offered to the pigs as for the rats $(0.73$ of the ad libitum digestible energy intake, equivalent to 0.10 metabolic body weight $\left(\mathrm{kg}\right.$ body weight $\left.{ }^{0 \cdot 75} / \mathrm{d}\right)$ ). Fresh water was freely available for both species.

On day 14 , and $7 \mathrm{~h}$ after the start of the meal, the rats were asphyxiated in $\mathrm{CO}_{2}$ gas and decapitated (immediately ceasing all neural stimulation to the gut), as described by Yu et al. $(1996 b)$. Ileal digesta were collected from the terminal $150 \mathrm{~mm}$ of ileum. The pigs were anaesthetized using halothane gas (Fluothane; Imperial Chemical Industries Ltd, Cheshire) and killed with a $20 \mathrm{ml}$ intracardial injection of sodium pentobarbitone (Anathal $60 \mathrm{mg} / \mathrm{ml}$; VR Laboratories, Thornleigh, NSW, Australia). Digesta were then removed from the terminal $450 \mathrm{~mm}$ of ileum. Ileal contents were slowly flushed out using deionized 
water and were frozen $\left(-20^{\circ}\right)$ immediately after collection, and then freeze-dried. The stomach contents of the rats were inspected for signs of faecal contamination which results from coprophagy.

\section{Chemical analysis}

Before analysis, samples of dieis and ileal digesta were ground in a laboratory mill with a $1.0 \mathrm{~mm}$ screen. The diets and ileal digesta were analysed in duplicate for total $\mathrm{N}$ using the Kjeldahl procedure, and crude protein was calculated as total $\mathrm{N} \times 6 \cdot 25$. The $\mathrm{Cr}$ contents of duplicate 20-30 mg samples of ileal digesta and each diet were determined by the method of Costigan \& Ellis (1987). The CT contents of the diets were determined using the method of Terrill et al. (1992). Free gossypol in the diets was estimated by the method of the American Oil Chemists Society (1975). The neutral-detergent fibre (NDF), acid-detergent fibre and lignin contents were determined by the method of Robertson \& van Soest (1981). The crude ash, crude oil and gross energy contents of the feeds were determined according to conventional methods (Association of Official Analytical Chemists, 1975).

Amino acid composition was determined on $10 \mathrm{mg}$ samples using HPLC (Waters Associates, USA). Duplicate samples were hydrolysed in $500 \mu 16 \mathrm{M}-\mathrm{HCl}$ with added phenol $(10 \mathrm{~g} / \mathrm{l})$, for $24 \mathrm{~h}$ at $110 \pm 1^{\circ}$ in glass tubes sealed under vacuum. The amino acids, methionine, cystine and tryptophan, which were partly destroyed during acid-hydrolysis, were not determined. Free amino acid MW were used to calculate the weights of the amino acids.

\section{Data analysis}

Apparent digestibility coefficients for DM, protein and amino acids were calculated using the following equation (Maynard et al, 1979):

$$
\text { apparent digestility }(\%)=100-100 \frac{\% \mathrm{Cr} \text { in feed }}{\% \mathrm{Cr} \text { in ileal digesta }} \times \frac{\% \text { nutrient in ileal digesta }}{\% \text { nutrient in feed }} .
$$

A linear statistical model, which included terms for heat, PEG and heat $\times$ PEG for Expt 1 and animal species, PEG and species $\times$ PEG for Expt 2, was fitted to the digestibility data for DM, protein and each amino acid singly, and reduction in sums of squares was used to determine levels of significance (Steel \& Torrie, 1980).

\section{RESULTS}

\section{Chemical composition}

The determined chemical composition of the cottonseed kernel, the hulls and their mixture, before and after heat treatment, and the commercial CSM is shown in Table 2. Protein and fibre (NDF) contents in the cottonseed kernel were 545 and $80 \mathrm{~g} / \mathrm{kg}$ respectively, and in the commercial CSM were 498 and $128 \mathrm{~g} / \mathrm{kg}$ respectively. Free gossypol content was lower in the kernel compared with commercial CSM $(0.6 v .0 .9 \mathrm{~g} / \mathrm{kg})$. Cottonseed hulls contained (g/kg DM): 45 protein, $750 \mathrm{NDF}, 0.3$ free gossypol, $46 \cdot 3$ total CT. Heat treatment of the kernel and hull mixture reduced the free gossypol concentration $(29 \%)$ and the total CT concentration measured with butanol-HCl $(29 \%)$, but did not affect the amino acid content.

\section{Expt 1}

The mean body weight of the rats at the end of the study was 222 (SD 12.0) $\mathrm{g}$. Mean feed intakes for the rats on day 13 of the study are given in Table 3. Feed intake was within the normal range for a rat of $220 \mathrm{~g}$ body weight (National Research Council, 1978). Dietary PEG addition did not appear to affect feed intake. On the last day of study the rats had 
Table 2. Chemical compositions ( $\mathrm{g} / \mathrm{kg} \mathrm{DM})$ of the unheated and heated solvent-extracted cottonseed kernels, cottonseed kernel and hulls, hulls and of the commercial cottonseed meal

(Mean values for duplicate determinations)

\begin{tabular}{|c|c|c|c|c|c|}
\hline & \multicolumn{3}{|c|}{ Cottonseed kernel } & \multirow{2}{*}{$\begin{array}{l}\text { Cottonseed } \\
\text { hulls } \\
\text { (pure, } \\
\text { unheated) }\end{array}$} & \multirow[b]{2}{*}{$\begin{array}{c}\text { Cottonseed } \\
\text { meal }\end{array}$} \\
\hline & $\begin{array}{c}\text { Pure, } \\
\text { unheated }\end{array}$ & $\begin{array}{c}\text { Unheated + } \\
\text { unheated } \\
\text { hulls* }\end{array}$ & $\begin{array}{c}\text { Heated }+ \\
\text { heated } \\
\text { hulls* }\end{array}$ & & \\
\hline $\mathrm{DM}(\mathrm{g} / \mathrm{kg})$ & 892 & 892 & 920 & 888 & 878 \\
\hline Crude protein $(\mathrm{N} \times 6.25)$ & 545 & 475 & 469 & 45 & 498 \\
\hline Oil & 117 & 103 & 97 & 17 & 21 \\
\hline Neutral-detergent fibre & 80 & 187 & 191 & 751 & 128 \\
\hline Acid-detergent fibre & 28 & 100 & 95 & 524 & 76 \\
\hline Lignin & 16 & 45 & 42 & 212 & 26 \\
\hline Free gossypol & 0.59 & 0.48 & $0 \cdot 34$ & 0.31 & 0.94 \\
\hline \multicolumn{6}{|l|}{ Condensed tannin ${ }^{\dagger}$} \\
\hline Extractable & ND & $2 \cdot 38$ & $0 \cdot 84$ & 13.68 & $0 \cdot 65$ \\
\hline Protein-bound & ND & $4 \cdot 58$ & $3 \cdot 88$ & $24 \cdot 64$ & 8.98 \\
\hline Fibre-bound & ND & 0.92 & $0 \cdot 90$ & $8 \cdot 03$ & 0.91 \\
\hline Total (calculated) & ND & $7 \cdot 88$ & 5.62 & $46 \cdot 34$ & $10 \cdot 54$ \\
\hline \multicolumn{6}{|l|}{ Essential amino acid } \\
\hline Arginine & $32 \cdot 1$ & $27 \cdot 0$ & $26 \cdot 7$ & $1 \cdot 1$ & $26 \cdot 2$ \\
\hline Histidine & $9 \cdot 9$ & $8 \cdot 6$ & $8 \cdot 7$ & 0.7 & $8 \cdot 0$ \\
\hline Isoleucine & $8 \cdot 5$ & $7 \cdot 1$ & $7 \cdot 5$ & 0.6 & 6.9 \\
\hline Leucine & $15 \cdot 8$ & $13 \cdot 4$ & $14 \cdot 0$ & $1 \cdot 0$ & $12 \cdot 9$ \\
\hline Lysine & $12 \cdot 1$ & $10 \cdot 3$ & $9 \cdot 7$ & $1 \cdot 0$ & $9 \cdot 7$ \\
\hline Phenylalanine & $14 \cdot 6$ & $13 \cdot 8$ & $12 \cdot 8$ & 0.8 & 11.9 \\
\hline Threonine & $9 \cdot 6$ & $8 \cdot 1$ & $8 \cdot 4$ & 0.7 & $7 \cdot 8$ \\
\hline Valine & $7 \cdot 7$ & $9 \cdot 7$ & $10 \cdot 2$ & $0 \cdot 8$ & $9 \cdot 5$ \\
\hline Total (calculated) & $110 \cdot 3$ & 98.0 & $98 \cdot 0$ & $6 \cdot 7$ & $92 \cdot 9$ \\
\hline \multicolumn{6}{|l|}{ Non-essential amino acid } \\
\hline Alanine & $10 \cdot 9$ & $9 \cdot 2$ & $9 \cdot 6$ & $0 \cdot 8$ & $9 \cdot 0$ \\
\hline Aspartic acid & $23 \cdot 7$ & $20 \cdot 2$ & $20 \cdot 8$ & 1.6 & $20 \cdot 5$ \\
\hline Glutamic acid & $40 \cdot 0$ & $39 \cdot 7$ & $40 \cdot 5$ & $2 \cdot 8$ & $40 \cdot 2$ \\
\hline Glycine & $11 \cdot 4$ & $9 \cdot 8$ & $10 \cdot 1$ & 0.8 & $9 \cdot 5$ \\
\hline Serine & $11 \cdot 3$ & $9 \cdot 7$ & $9 \cdot 9$ & $1 \cdot 0$ & $9 \cdot 2$ \\
\hline Tyrosine & $8 \cdot 6$ & $7 \cdot 1$ & $7 \cdot 3$ & 0.7 & 6.6 \\
\hline Total (calculated) & 105.9 & $95 \cdot 7$ & $98 \cdot 2$ & $7 \cdot 7$ & $95 \cdot 0$ \\
\hline
\end{tabular}

ND, not determined.

* Cottonseed kernel $(300 \mathrm{~g} / \mathrm{kg})+50 \mathrm{~g}$ hulls $/ \mathrm{kg}$.

$\dagger$ Present in hulls, but not in kernels (Yu et al. 1993).

relatively high feed intakes over the first two hourly meals and then consumed generally even-sized meals for the remainder of the feeding period (Table 3). The latter was important to ensure an even flow of digesta at the terminal ileum. Faeces were not detected in the gastric contents at slaughter, indicating that coprophagy had not occurred at least on the last day of study.

Heat treatment significantly depressed $(P<0.001)$ ileal DM digestibility and the apparent ileal digestibility of $\mathrm{N}$ (Table 4). Dietary supplementation with PEG significantly increased ileal DM digestibility $(P<0.05)$ and apparent ileal $\mathrm{N}$ digestibility $(P<0.001)$. There was no significant interaction between heat treatment and PEG for either ileal DM digestibility or the apparent ileal digestibility of $\mathrm{N}$.

Apparent ileal amino acid digestibility for rats fed on the cottonseed kernel and hulls- 
Table 3. Expt. 1.* Mean intakes of diets containing heated and unheated solvent-extracted cottonseed kernel and hulls for the growing rats on day 13 and hourly meal intakes for the last day (day 14) of study

(Mean values for six animals per dietary treatment)

\begin{tabular}{|c|c|c|c|c|c|c|c|c|c|}
\hline \multirow[b]{2}{*}{ Diet } & \multirow{2}{*}{$\begin{array}{c}\text { Feed intake } \\
\text { on day } 13 \\
\text { (g) }\end{array}$} & \multicolumn{8}{|c|}{ Hourly meal intakes on day $14 \uparrow$} \\
\hline & & 1 & 2 & 3 & 4 & 5 & 6 & 7 & Total \\
\hline \multicolumn{10}{|c|}{$\begin{array}{l}\text { Cottonseed kernel }(300 \mathrm{~g} / \mathrm{kg}) \text { and } \\
\text { hulls }(50 \mathrm{~g} / \mathrm{kg}) \text { : }\end{array}$} \\
\hline PEG - & $16 \cdot 3$ & $3 \cdot 0$ & $2 \cdot 7$ & $2 \cdot 1$ & $2 \cdot 2$ & $2 \cdot 2$ & $1 \cdot 5$ & 0.7 & $14 \cdot 4$ \\
\hline PEG + & $16 \cdot 3$ & $2 \cdot 8$ & $2 \cdot 3$ & $2 \cdot 0$ & 1.9 & $2 \cdot 2$ & $1 \cdot 5$ & $0 \cdot 7$ & $13 \cdot 4$ \\
\hline \multicolumn{10}{|c|}{ Heated cottonseed kernel and hulls: } \\
\hline PEG - & $15 \cdot 6$ & $3 \cdot 5$ & $3 \cdot 0$ & $2 \cdot 0$ & $2 \cdot 2$ & $2 \cdot 6$ & $1 \cdot 0$ & 0.7 & $15 \cdot 0$ \\
\hline PEG + & $16 \cdot 5$ & $3 \cdot 0$ & $2 \cdot 5$ & $2 \cdot 0$ & 1.9 & $2 \cdot 1$ & $1 \cdot 2$ & $1 \cdot 2$ & 13.9 \\
\hline
\end{tabular}

PEG -, no PEG in the diet; PEG +, PEG (molecular wt 3500) included in the diet.

* For details of procedures, see pp. $360-363$.

$\uparrow$ Day of sampling ileal digesta.

Table 4. Expt 1.† Mean apparent digestibility of DM, total nitrogen and amino acids determined at the terminal ileum of growing rats given diets containing heated and unheated solvent-extracted cottonseed kernel and hulls

(Mean values for six animals per dietary treatment)

\begin{tabular}{|c|c|c|c|c|c|c|c|c|}
\hline & \multicolumn{4}{|c|}{ Cottonseed kernel and hulls diet } & \multirow{3}{*}{$\begin{array}{l}\text { Overall } \\
\text { SE }\end{array}$} & \multirow{2}{*}{\multicolumn{3}{|c|}{$\begin{array}{l}\text { Statistical significance } \\
\text { of effects of: }\end{array}$}} \\
\hline & \multicolumn{2}{|c|}{ Unheated } & \multicolumn{2}{|c|}{ Heated } & & & & \\
\hline & PEG - & PEG + & PEG - & PEG + & & Heat $(\mathrm{H})$ & PEG (P) & $\mathrm{H} \times \mathrm{P}$ \\
\hline DM & 0.74 & 0.76 & $0 \cdot 70$ & $0 \cdot 72$ & 0.008 & $* * *$ & $*$ & NS \\
\hline $\mathbf{N}$ & 0.79 & 0.86 & $0 \cdot 70$ & 0.74 & 0.014 & $* * *$ & $* * *$ & NS \\
\hline \multicolumn{9}{|c|}{ Essential amino acid } \\
\hline Arginine & 0.92 & 0.93 & 0.86 & $0 \cdot 88$ & 0.007 & $* * *$ & $P=0.08$ & NS \\
\hline Histidine & 0.88 & 0.89 & 0.87 & 0.87 & 0.012 & NS & NS & NS \\
\hline Isoleucine & 0.75 & 0.78 & $0-64$ & 0.68 & 0.010 & $* * *$ & $* *$ & NS \\
\hline Leucine & 0.78 & 0.80 & $0 \cdot 69$ & 0.71 & 0.010 & $* * *$ & $* *$ & NS \\
\hline Lysine & 0.77 & 0.80 & $0 \cdot 58$ & 0.64 & 0.008 & $* * *$ & $* * *$ & $P=0.06$ \\
\hline Phenylalanine & 0.84 & 0.86 & $0 \cdot 78$ & $0 \cdot 81$ & 0.006 & $* * *$ & ** & NS \\
\hline Threonine & 0.69 & 0.69 & $0 \cdot 56$ & 0.62 & 0.013 & $* * *$ & $P=0.06$ & $*$ \\
\hline Valine & 0.78 & $0 \cdot 80$ & $0 \cdot 69$ & 0.72 & 0.009 & $* * *$ & $* *$ & NS \\
\hline \multicolumn{9}{|c|}{ Non-essential amino acid } \\
\hline Alanine & 0.77 & $0 \cdot 80$ & $0 \cdot 66$ & 0.71 & 0.010 & $* * *$ & $* * *$ & NS \\
\hline Aspartic acid & 0.83 & 0.85 & $0 \cdot 70$ & 0.75 & 0.014 & $* * *$ & $* *$ & NS \\
\hline Glutamic acid & 0.88 & 0.90 & $0 \cdot 79$ & 0.82 & 0.009 & $* * *$ & $* *$ & NS \\
\hline Glycine & 0.73 & 0.77 & 0.56 & 0.61 & 0.011 & $* * *$ & $* * *$ & NS \\
\hline Serine & 0.77 & 0.80 & 0.67 & 0.70 & 0.010 & $* * *$ & $* *$ & NS \\
\hline Tyrosine & $0 \cdot 80$ & 0.82 & $0 \cdot 71$ & $0 \cdot 83$ & 0.008 & $* * *$ & $* * *$ & $* * *$ \\
\hline
\end{tabular}

PEG -, no PEG in the diet; PEG +, PEG (molecular wt 3500) included in the diet.

* $P<0.05, * * P<0.01, * * * P<0.001$.

$\dagger$ For details of procedures, see p. 360-363. 
Table 5. Expt 2†. Mean apparent digestibility of DM, total nitrogen and amino acids determined at the terminal ileum of growing rats and pigs given a commercial cottonseed mealbased diet

(Mean values for six animals per dietary treatment)

\begin{tabular}{|c|c|c|c|c|c|c|c|c|}
\hline & \multicolumn{4}{|c|}{ Cottonseed meal diet } & \multirow{3}{*}{$\begin{array}{l}\text { Overall } \\
\text { SE }\end{array}$} & \multirow{2}{*}{\multicolumn{3}{|c|}{$\begin{array}{c}\text { Statistical significance } \\
\text { of effects of : }\end{array}$}} \\
\hline & \multicolumn{2}{|c|}{ Rat } & \multicolumn{2}{|c|}{ Pig } & & & & \\
\hline & PEG - & PEG + & PEG - & PEG + & & $\begin{array}{l}\text { Species } \\
\text { (S) }\end{array}$ & PEG (P) & $\mathbf{S} \times \mathbf{P}$ \\
\hline DM & 0.70 & 0.70 & 0.63 & $0 \cdot 66$ & $0 \cdot 011$ & $* * *$ & NS & NS \\
\hline $\mathrm{N}$ & 0.69 & $0 \cdot 71$ & 0.66 & $0 \cdot 70$ & 0.010 & $P=0 \cdot 08$ & $* *$ & NS \\
\hline \multicolumn{9}{|c|}{ Essential amino acid } \\
\hline Arginine & 0.85 & 0.87 & 0.85 & $0 \cdot 85$ & 0.006 & $*$ & NS & NS \\
\hline Histidine & $0-87$ & 0.87 & 0.77 & $0-76$ & 0.012 & $* * *$ & NS & NS \\
\hline Isoleucine & 0.57 & 0.62 & 0.61 & 0.64 & 0.012 & $*$ & $* *$ & NS \\
\hline Leucine & 0.62 & 0.65 & 0.64 & 0.66 & 0.011 & NS & $*$ & NS \\
\hline Lysine & 0.50 & 0.52 & 0.58 & 0.59 & $0 \cdot 013$ & $* * *$ & NS & NS \\
\hline Phenylalanine & 0.76 & 0.77 & 0.75 & 0.78 & $0 \cdot 010$ & NS & $P=0.09$ & NS \\
\hline Threonine & 0.50 & 0.53 & 0.56 & 0.58 & $0 \cdot 009$ & $* * *$ & * & NS \\
\hline Valine & 0.63 & 0.66 & 0.64 & 0.67 & 0.010 & NS & $*$ & NS \\
\hline \multicolumn{9}{|c|}{ Non-essential amino acid } \\
\hline Alanine & 0.60 & 0.63 & 0.60 & 0.63 & $0 \cdot 012$ & NS & * & NS \\
\hline Aspartic acid & 0.70 & 0.71 & 0.70 & $0-74$ & 0.010 & NS & $*$ & NS \\
\hline Glutamic acid & $0 \cdot 79$ & 0.81 & $0 \cdot 76$ & 0.78 & $0-007$ & $* * *$ & $*$ & NS \\
\hline Glycine & 0.54 & 0.62 & 0.60 & 0.62 & $0 \cdot 011$ & $* *$ & $* * *$ & $* *$ \\
\hline Serine & 0.61 & 0.64 & 0.63 & 0.66 & $0 \cdot 010$ & $*$ & $* *$ & NS \\
\hline Tyrosine & 0.68 & 0.69 & 0.67 & 0.70 & $0 \cdot 008$ & NS & $*$ & NS \\
\hline
\end{tabular}

PEG -, no PEG in the diet; PEG +, PEG (molecular wt 3500) included in the diet.

${ }^{*} P<0.05, * * P<0.01, * * * P<0.001$.

+ For details of procedures, see pp. 360-363.

based diet was significantly reduced by the heat treatment (Table 4) for all amino acids except histidine, and the reduction was particularly marked for lysine and threonine. On average, apparent ileal amino acid digestibility in the diets without PEG addition was decreased from $0-80$ to 0.70 by the heat treatment. Addition of PEG to diets containing either the heated or unheated cottonseed kernel and hulls led to a significant increase in apparent ileal amino acid digestibility. The results indicate that heat treatment had a major effect on decreasing the protein quality of the cottonseed kernel and that CT in the diet further depressed the ileal digestibility of amino acids. Histidine digestibility was not affected by heat treatment nor by PEG addition to the diets.

There were no statistically significant interactions $(P>0.05)$ between heat treatment and PEG for apparent amino acid digestibility, except for threonine and tyrosine. The significant heat $\times$ PEG interactions for threonine $(P<0.05)$ and tyrosine $(P<0.001)$ were explained by the responses to PEG being greater on heated than on unheated cottonseed kernel and hulls. A similar trend was evident for lysine, with the interaction attaining significance at $P=0 \cdot 06$.

\section{Expt 2}

The mean body weights at the end of the study were 242 (SD 11.1) $\mathrm{g}$ and 29 (SD 1.7) $\mathrm{kg}$ for the rats and pigs respectively. All animals consumed the diets readily and were fully accustomed to the feeding procedure after $7 \mathrm{~d}$. On average, the rats and pigs consumed 
$17.6 \mathrm{~g}$ and $1.35 \mathrm{~kg}$ meal respectively on the day before slaughter. None of the animals used in the experiment showed evidence of ingested faeces in the stomach at slaughter and, therefore, coprophagy was not considered to be of significance.

The apparent ileal digestibility values for DM, $\mathbf{N}$ and amino acids for the rats and pigs given the commercial CSM, including or excluding dietary PEG, are given in Table 5. The ileal digestibility of DM and the apparent ileal digestibility of $\mathrm{N}$ tended to be lower for the pig than for the rat. Also, for several of the amino acids there were significant species differences in apparent ileal digestibility.

The addition of dietary PEG to the commercial-CSM-based diets significantly increased the apparent ileal digestibility of $N(P<0.01)$ for both the rats and the pigs, but did not affect ileal DM digestibility (Table 5). The effects of PEG addition on apparent ileal amino acid digestibility were similar for the two animal species. Inclusion of dietary PEG led to an increase in the apparent ileal digestibility of the individual amino acids for glycine ( $P$ $<0.001)$, isoleucine, serine $(P<0.01)$, leucine, threonine, valine, alanine, tyrosine, aspartic acid and glutamic acid $(P<0 \cdot 05)$. The apparent ileal digestibility of the remaining amino acids tended to increase with the addition of PEG, but the differences were not statistically significant $(P>0.05)$. The mean increase in apparent ileal digestibility for the fourteen amino acids, due to the addition of the PEG $(12 \mathrm{~g} / \mathrm{kg})$ to the CSM diet, was 2 percentage units. The species $\times$ PEG interaction was not statistically significant, except for the non-essential amino acid, glycine. The commercial CSM had a low apparent ileal amino acid digestibility overall.

\section{DISCUSSION}

The present values for apparent ileal amino acid digestibility for the rats fed on the solventextracted cottonseed kernel and for the pigs fed on the commercial CSM are generally similar to those of previous determinations ( $Y u$ et al. 1996b) and of other reports in the literature (Taverner et al. 1983; Sauer \& Ozimek, 1986; Baterham et al. 1990). The apparent ileal digestibility coefficients for the CSM amino acids were generally low and this was particularly so for lysine, threonine and glycine.

Although the heat treatment used in Expt 1 appeared to inactivate about $29 \%$ of the total CT, which has been observed previously (Yu et al. 1996a), such that it could not be extracted and detected with butanol- $\mathrm{HCl}$, the heat treatment applied did not reduce the amount of reversible binding by CT as judged by the responses to PEG. Similar results were found by Yu et al. (1996a) in studying the effect of heat treatment on N solubility and the rumen degradation of cottonseed proteins. Rather, the increased responses to PEG in apparent ileal digestibility of threonine, tyrosine and lysine in heated compared with unheated CSM suggests that action of autoclaving at $110^{\circ}$ for $2 \mathrm{~h}$ may in fact have increased the reactivity of CT with these amino acids causing large reductions in digestibility. This clearly requires further study. Action of PEG in Expt 2 also increased apparent ileal digestibility of many amino acids in both rats and pigs fed on commerciallyproduced CSM. However, for the two limiting essential amino acids lysine and threonine, the responses were much less for commercial CSM (1-3 percentage units; Expt 2) than for heated CSM prepared under laboratory conditions ( 6 percentage units; Expt 1), perhaps indicating some irreversible binding under commercial conditions. The commercial CSM was produced by pre-press solvent extraction, and whilst it is possible to duplicate in the laboratory the amount of heat used to drive off residual hexane solvent (as done in Expt 1), no attempt was made to duplicate the effects on nutritive value of the heat and pressure produced during screw pressing. Further studies are needed on the interactions between temperature, time, moisture content, pressure and CT on the ileal digestibility of amino acids in CSM. 
The value of dietary protein to single-stomached animals is influenced greatly by the proportion of the protein that can be digested and absorbed. The effect of heat treatment, which leads to a reduction in protein digestion and amino acid absorption in the gut, has been extensively reviewed by Hurrell \& Carpenter (1977) and Erbersdobler \& Anderson (1983). In addition to the effects of sugar-protein Maillard reaction and isopeptide crosslinks, it is well known that gossypol can also react with protein-amino groups. As a number of amino acids, such as lysine, threonine, methionine and tryptophan, are affected by heat treatment (Batterham, 1992), it is possible that chemical reactions occur between amino acids within a protein molecule, in addition to the specific Maillard reaction between lysine and carbonyl groups of reducing sugars. As such, other amino acids in addition to those mentioned previously may also be affected. In the present studies, heat treatment of CSM by autoclaving for $120 \mathrm{~min}$ significantly reduced the apparent ileal digestibility of all individual amino acids except histidine. A finding of relevance to the present work is that of Moughan et al. (1996), who found that the apparent ileal digestibility of most amino acids for pigs fed on a heated glucose-casein mixture was lower compared with an unheated mixture.

In the present study, whereas lysine was considerably less digestible than the other amino acids in the heated cottonseed materials and commercial CSM for both rats and pigs, this was not so for the rats fed on the unheated cottonseed materials. It is known that, because of its free $\epsilon$-amino group, lysine is the amino acid which is primarily affected when heat is applied to cottonseed protein (Erbersdobler \& Anderson, 1983). In addition the loss of available lysine in CSM is due partly to its reaction with the pigment gossypol present in cottonseed (Berardi \& Goldblatt, 1980), but other compounds are also involved (Martinez et al. 1967). A low apparent ileal digestibility of threonine in heated materials was also found in the present study. Batterham (1992) suggested that for lysine, threonine, methionine and tryptophan, heat induces changes which depress ileal digestibility slightly but result in a substantial proportion of these amino acids apparently being absorbed in inefficiently-utilized forms. Thus, the conventional ileal digestibility assay may be unsuitable for fully assessing availability in heat-damaged meals.

The observed lower apparent ileal digestibility of protein and amino acids for pigs fed on the CSM diets without PEG compared with those fed on diets containing PEG found in the present studies can be attributed to the effects of dietary CT. PEG can specifically combine with CT to form CT-PEG complexes and the bonds in these complexes are stronger than the bonds in CT-protein complexes. Thus, PEG can be used to displace protein from the CT-protein complexes without affecting the nutritional composition of the diet (Jones \& Mangan, 1977). Previous studies with PEG have shown that PEG addition per se had no intrinsic effect on protein digestibility in the absence of CT (Yu et al. $1995 b, 1996 b$ ). In the present study it was assumed that PEG completely bound with the CT released during digestion of the diets containing cottonseed hulls and CSM, and comparison between diets including or not including PEG allowed the effect of cottonseed CT to be defined.

The effects of CT in depressing apparent ileal protein digestibility may be explained either by a direct binding of CT to dietary proteins, by a reduced activity of proteindegrading enzymes (Longstaff \& McNab, 1991; Jansman, 1993), or by an increased secretion of endogenous proteins (Marquardt, 1989; Jansman, 1993). However, in recent work, no effect of cottonseed CT on endogenous ileal amino acid flow determined in the rat was found (Yu et al. 1995b). Commercial CSM produced in Australia contains between 150 and $300 \mathrm{~g}$ hulls $/ \mathrm{kg}$ and has a CT content of $8-15 \mathrm{~g} / \mathrm{kg} \mathrm{DM}, 92 \%$ of which is bound to protein and fibre (Yu et al. 1993). Bound CT can react with protein in the digestive system of the single-stomached animal (Yu et al. 1996b), although they appear to be 
relatively unreactive in the rumen ( $\mathrm{pH} 7.0$; Yu et al. 1995a). A possible explanation for the present result is that bound cottonseed CT were solubilized and released in the stomach of the pigs and were then available to react with proteins in the small intestine. The results obtained from rats in the present and previous studies (Yu et al. 1996 b) are in line with the present result for pigs.

The third objective of the present study was to determine whether the laboratory rat is an acceptable model animal for determining ileal amino acid digestibility in CSM for the growing pig. For an inter-species comparison of digestion to be valid, the species should be examined under physiologically-comparable conditions. There appear to be major similarities between the rat and pig in digestive anatomy and physiology (Church \& Pond, 1988), requirements for nutrients (National Research Council, 1978) and relative growth rates (Pullar \& Webster, 1977), especially when comparison is made at a physiologicallycomparable age (Donkoh et al. 1994). The body weights of both rats and pigs in the present study were selected to correspond to the period of growth after weaning. The mean body weight of the rats $(190 \mathrm{~g})$ corresponded to $35 \%$ of mature body weight (National Research Council, 1978), while that for the pigs corresponded to $12 \%$ of mature weight (Pond \& Houpt, 1978). Although the body weights relative to mature weight were different, the rats (National Research Council, 1962) and pigs (Headley et al. 1961) should have been in their linear phase of growth and so there should not have been any major differences in the stage of development of their digestive systems. Further, the levels of feed intake in the present experiments were chosen so that relative food intake was comparable between the species.

Other studies (Taverner, 1979; Picard et al. 1984; Smith et al. 1990; Donkoh et al. 1994) have shown similarities between rats and pigs for ileal amino acid digestibility in several protein sources. However, this may not be so for all feedstuffs and particularly for feedstuffs containing ANF. Several studies indicate that rats and piglets may respond differently to ANF in raw soyabean (Coms et al. 1967) and chickpeas (Cicer arietinum; Visitpanich et al. 1985). Moreover, Moughan et al. (1984) found significant differences between rats and pigs for apparent ileal protein digestibility in peas. Huisman \& van der Poel (1989) and Huisman et al. (1991) compared the sensitivity of various animal species (pigs, rats, chickens and mice) to ANF in legume seeds and demonstrated that piglets were distinctly more sensitive to ANF in beans and peas than rats and chickens and that results obtained with rats and chickens cannot be extrapolated to pigs. The findings of the present study indicate that there are significant differences in the apparent ileal digestibility of some amino acids in CSM between rats and pigs and particularly for the key amino acids, lysine and threonine. However, the pig was not distinctly more sensitive to cottonseed CT than the rat.

In summary, dietary cottonseed CT depressed apparent ileal protein digestibility for both the rat and the pig. Heat treatment $\left(110^{\circ}\right.$ for $\left.2 \mathrm{~h}\right)$ did not diminish the reversible reactivity of CT with cottonseed protein in the small intestine of rats but rather appeared to increase it for threonine, tyrosine and lysine. There were differences in the apparent ileal digestibility of some amino acids in CSM between rats and pigs. Therefore, studies into the effects of CT should be carried out in the target animal species. Heat treatment significantly reduced apparent ileal amino acid digestibility in CSM, particularly for the essential amino acids lysine and threonine. In general, the CT effects in reducing apparent ileal amino acid digestibility of CSM were of smaller magnitude than those produced by heat treatment, but combinations of heat and CT were particularly detrimental in reducing apparent ileal digestibility of threonine, tyrosine and lysine.

This study was supported by a grant from the Australian Cotton Research \& Development Corporation. The authors thank Cotton Seed Distributors Ltd, Wee Waa, NSW, Australia 
for supplying cottonseed, Cargill Oilseeds Ltd, Australia for supplying CSM, and Ms J. Wood and Ms M. L. Zou of the Department of Animal Science, Massey University for their skilled technical assistance.

\section{REFERENCES}

Association of Official Analytical Chemists (1975). Official Methods of Analysis, 12th ed. Washington, DC: Association of Official Analytical Chemists.

American Oil Chemists Society (1975). Official and Tentative Methods of American Oil Chemists Society, 3rd ed., p. Ba7-58. Champaign, IL. : American Oil Chemists Society.

Batterham, E. S. (1992). Availability and utilization of amino acids for growing pigs. Nutrition Research Reviews $5,1-18$.

Batterham, E. S., Anderson, L. M., Baigent, D. R., Beech, S. A. \& Elliott, R. (1990). A comparison of the availability and ileal digestibility of lysine in cottonseed and soybean meals for grower/finisher pigs. British Journal of Nutrition 64, 663-677.

Berardi, L. C. \& Goldblatt, L. A. (1980). Gossypol. In Toxic Constituents of Plant Foodstuffs, pp. 183-237 [I. E. Liener, editor]. New York, London and Sydney: Academic Press.

Church, D. C. \& Pond, W. G. (1988). The gastrointestinal tract and nutrition. Basic Animal Nutrition and Feeding, 3rd ed., pp. 27-47. New York: Wiley.

Coms, G. E., Connes, R. G., Berry, T. H. \& Wallace, H. D. (1967). Effect of raw and heated soyabeans on gain, nutrient digestibility, plasma amino acids and other blood constituents of growing swine. Journal of Animal Science 26, 1067-1071.

Costigan, P. \& Ellis, K. J. (1987). Analysis of faecal chromium derived from controlled release marker devices. New Zealand Journal of Technology 3, 89-92.

Donkoh, A., Moughan, P. J. \& Smith, W. C. (1994). The laboratory rat as a model animal for determining ileal amino acid digestibility in meat and bone meal for the growing pig. Animal Feed Science and Technology 49, $57-71$

Erbersdobler, H. F. \& Anderson, T. R. (1983). Determination of the available lysine by various procedures in Maillard type products. In The Maillard Reaction in Foods and Nutrition. ACS Symposium Series, vol. 215, pp. 419-427, [G. R. Waller and M. S. Feather, editors]. Washington, DC: ACS.

Ford, J. E. \& Shorrock, C. (1971). Metabolism of heat-damaged proteins in the rat. Influence of heat damage on the excretion of amino acids and peptides in the urine. British Journal of Nutrition 26, 311-322.

Headley, V. E., Miller, R. E., Ullrey, D E. \& Hoefer, J. A. (1961). Applications of the equation of the curve of diminishing increment to swine nutrition. Journal of Animal Science 20, 311-315

Huisman, J. \& van der Poel, A. F. B. (1989). Comparison of effects of antinutritional factors (ANF) in different animal species. In Recent Advances of Research in Antinutritional Factors in Legume Seeds, pp. 317-327 [J. Huisman, A. F. B. van der Poel and I. E. Liener, editors]. Wageningen, The Netherlands: Pudoc Wageningen.

Huisman, J., van der Poel, A. F. B. \& Beynen, A. C. (1991). Animal species differences in antinutritional effects of raw Phaseolus vulgaris beans and Pisum sativum: comparison of piglets, rats, chickens and mice. In Proceedings of the Vth International Symposium on Digestive Physiology in Pigs, pp. 108-113 [M. W. A. Verstegen, J. Huisman and L. A. den Hartog, editors]. Wageningen, The Netherlands: Pudoc Wageningen.

Hurrell, R. F. \& Carpenter, K. J. (1977). Nutritional significance of cross-link formation during food processing. In Protein Crosslinking: Biochemical, Medical, and Nutritional Consequences, pp. 225-238 [M. Friedman, editor]. New York: Plenum Press.

Jansman, A. J. M. (1993). Tannins in faba beans (Vicia Faba L. ) - antinutritional properties in monogastric animals. PhD Thesis. Wageningen Agricultural University, The Netherlands.

Jones, W. T. \& Mangan, J. L. (1977). Complexes of the condensed tannins of sainfoin (Onobrychis viciifolia Scop.) with Fraction 1 Leaf protein and with submaxillary mucoprotein, and their reversal by polyethylene glycol and pH. Journal of the Science of Food and Agriculture 28, 126-136.

Longstaff, M. \& McNab, J. M. (1991). The inhibitory effects of hull polysaccharides and tannins of field beans (Vicia faba L. ) on the digestion of amino acids, starch and lipid and on digestive enzyme activities in young chicks. British Journal of Nutrition 65, 199-216.

Marquardt, R. R. (1989). Dietary effects of tannins, vivine and convicine. In Recent Advances of Research in Antinutritional Factors in Legume Seeds, pp. 141-155 [J. Huisman, A. F. B. van der Poel and I. E. Liener, editors]. Wageningen, The Netherlands: Pudoc Wageningen.

Martinez, W. H., Berardi, L. C., Frampton, V. L., Eilcke, H. L., Green, D. E. \& Teichman, R. (1967). Importance of cellular constituents to cottonseed meal protein quality. Journal of Agricultural and Food Chemistry 15, $427-432$.

Maynard, L. A., Loosli, J. K., Hintz, H. F. \& Warner, R. G. (1979). Animal Nutrition. New Delhi, India: McGraw-Hill, Inc. 
Mehansho, H., Hagerman, A., Clements, S., Butler, L. G., Rogler, J. C. \& Carlson, D. M. (1983). Modulation of proline-rich protein biosynthesis in rat parotid glands by sorghum with high tannin levels. Proceedings of the National Academy of Sciences, USA 80, 3948-3952.

Moughan, P. J., Gall, M. P. J. \& Rutherfurd, S. M. (1996). Forms of lysine in an early Maillard browned casein and the absorption of lysine and deoxyketosyl lysine by the growing pig. Journal of Agricultural and Food Chemistry (In the Press).

Moughan, P. J., Smith, W. C. \& James, K. A. C. (1984). Preliminary observations on the use of the rat as a model for the pig in the determination of apparent digestibility of dietary proteins. New Zealand Journal of Agriculture Research 27, 509-512.

National Research Council (1962). Nutrient requirements of the laboratory rat. Nutrient Requirements of Laboratory Animals. National Academy of Sciences Publication no. 990, pp. 51-95. Washington, DC: National Academy of Sciences.

National Research Council (1978). Nutrient requirements of the laboratory rat. Nutrient Requirements of Laboratory Animals, 3rd ed., pp. 7-32. Washington DC: National Academy of Sciences.

Picard, M., Bertrand, S., Duron, M. \& Dunnigan, J. (1984). Comparative digestibility of amino acids using 5 animal models: intact cockerel, caecectomized cockerels, rat deprived of large intestine, piglet with an ileocaecal cannulation, piglet with an ileo-rectal shunt. In Proceedings IVth European Symposium on Poultry Nutrition, p. 165 [M. Larbier, editor]. Tours, France: World's Poultry Science Association.

Pond, W. G. \& Houpt, K. A. (1978). The pig as a model in biomedical research. The Biology of the Pig, pp. 13-43. Ithaca, NY: Comstock Publishing.

Pons, W. A. \& Eaves, P. H. (1967). Aqueous acetone extraction of cottonseed. Journal of American Oil Chemists Society 44, 460-464.

Pullar, J. D. \& Webster, A. J. F. (1977). The energy cost of fat and protein deposition in the rat. British Journal of Nutrition 37, 355-363.

Robertson, J. B. \& van Soest, P. J. (1981). The detergent system of analysis and its application in human food. In The Analysis of Dietary Fibre in Food, pp. 123-158 [W. P. T. James and O. Theander, editors]. New York and Basel: Marcel Dekker Inc.

Sauer, W. C. \& Ozimek, L. (1986). Digestibility of amino acids in swine: results and their practical applications. A review, Livestock Production Science 15, 367-388.

Smith, W. C., Moughan, P. J. \& James, K. A. C. (1990). Comparative apparent ileal digestibility of amino acids in a mixed meal diet measured with the growing rat and pig. New Zealand Journal of Agricultural Research 33 , $669-671$

Steel, R. G. D. \& Torrie, J. H. (1980). Principles and Procedures of Statistics. New York: McGraw-Hill.

Taverner, M. R. (1979). Ileal availability for pigs of amino acids in cereal grains. PhD Thesis, University of New England, Armidale, NSW, Australia.

Taverner, M. R., Curic, D. M. \& Rayner, C. J. (1983). A comparison of the extent and site of energy and protein digestion of wheat, lupin and meat and bone meal by pigs. Journal of the Science of Food and Agriculture 34, $122-128$

Terrill, T. H., Rowan, A. M., Douglas, G. B. \& Barry, T. N. (1992). Determination of extractable and bound condensed tannin concentrations in forage plants, protein concentrate meals and cereal grains. Journal of the Science of Food and Agriculture 58, 321-329.

Visitpanich, T., Batterham, E. C. \& Norton, B. W. (1985). Nutritional value of chickpea (Cicer arietinum) and pigeon pea (Cajanus cajan) meals for growing pigs and rats. II. Effect of autoclaving and alkali treatment. Australian Journal of Agricultural Research 36, 327-335.

Yu, F, Barry, T. N., McNabb, W. C., Moughan, P. J. and Wilson, G. F. (1995a). Effect of bound condensed tannin from cottonseed upon in situ protein solubility and dry matter degradation in the rumen. Journal of the Science of Food and Agriculture 69, 311-319.

Yu, F., Barry, T. N., Moughan, P. J. \& Wilson, G. F. (1993). Condensed tannin and gossypol concentrations in cottonseed and in processed cottonseed meal. Journal of the Science of Food and Agriculture 63, 7-15.

Yu, F., McNabb, W. C., Barry, T. N. \& Moughan, P. J. (1996a). Effect of heat treatment upon the chemical composition of cottonseed meal and upon the reactivity of cottonseed condensed tannins. Journal of the Science of Food and Agriculture (In the Press).

Yu, F., Moughan, P. J. \& Barry, T. N. (1995b). Effect of condensed tannin in cottonseed hulls on endogenous ileal amino acid loss in the growing rats. Journal of the Science of Food and Agriculture 68, 451-455.

Yu, F., Moughan, P. J. \& Barry, T. N. (1996b). The effect of cottonseed condensed tannins on the ileal digestibility of amino acids in casein and cottonseed kernel. British Journal of Nutrition 75, 683-698. 